« Robust structural determinants of public deficits in developing countries »

\author{
$\underline{\text { Auteurs }}$ \\ Blaise Gnimassoun, Isabelle Do Santos \\ Document de Travail n $2020-15$
}

Bureau d'Économie

Théorique et Appliquée BETA

www.beta-umr7522.fr

@beta_economics

Contact :

jaoulgrammare@beta-cnrs.unistra.fr 


\title{
Robust structural determinants of public deficits in developing countries*
}

\author{
Blaise Gnimassoun ${ }^{\dagger}$ \& Isabelle Do Santos ${ }^{\ddagger}$
}

\begin{abstract}
Many macroeconomic, institutional, demographic, social and political variables have been proposed by previous studies as significant determinants of public deficits in developing countries. This paper asks whether their estimated impact on public deficits is robust under thousands of possible alternative specifications. We deal with model uncertainty using Sala-i-Martin's Extreme Bound Analysis. Our results clearly show that external shocks, the debt ratio, financial development, the level of democracy and government control over expenditures are robustly associated with fiscal deficits. Public deficits are lower in countries which provide better stability of public expenditure in the face of revenue instability and which are less exposed to negative external shocks. In contrast, fiscal deficits increase with the debt ratio, financial development and the level of democracy. The relative importance of external shocks in all the regressions argues in favour of greater economic diversification in order to mitigate the impact of negative shocks on public finances.
\end{abstract}

Key Words: Fiscal policy; Budget deficits; Sensitivity analysis; Robust regressions.

JEL Classification : E62; H61; H62; C31.

${ }^{*}$ Corresponding author: Blaise Gnimassoun, University of Lorraine, BETA, CNRS, INRA, 54000, Nancy and EconomiX, France; Email: blaise.gnimassoun@univ-lorraine.fr. Phone. +33 (0) 3727420 92; Fax: +33 (0) 372742071.

†University of Lorraine, BETA, CNRS, INRA, 54000, Nancy and EconomiX, France; Email: blaise.gnimassoun@univ-lorraine.fr.

$\ddagger$ University of Lorraine, BETA, CNRS, INRA, 54000, Nancy France; Email: isabelle.dosantos@univ-lorraine.fr. 


\section{Introduction}

Emerging markets and developing economies (EMDE) have faced large and persistent budget deficits since the 2008 economic crisis. As Figure 1 shows, all of the emerging and developing regions are on average affected by the deterioration of public finances over the decade 2009-2018, both for the overall balance and for the primary balance. However, the size of the primary deficit is relatively greater for sub-Saharan Africa (SSA) while the overall deficit is more pronounced for Latin America and the Caribbean (LAC). The joint observation of primary and global balances clearly shows the harmful impact of public debt on public finances. In addition, the primary deficits observed over this period are also likely to maintain the negative spiral of debt. Such a situation obviously raises the question of the medium- and long-term sustainability of public finances in these countries. The concern is all the more relevant as the spectre of the public finance and debt crisis of the 1980s and 1990s still hangs over these countries.

Figure 1: Fiscal balances in emerging and developing countries during the 2009-2018 decade

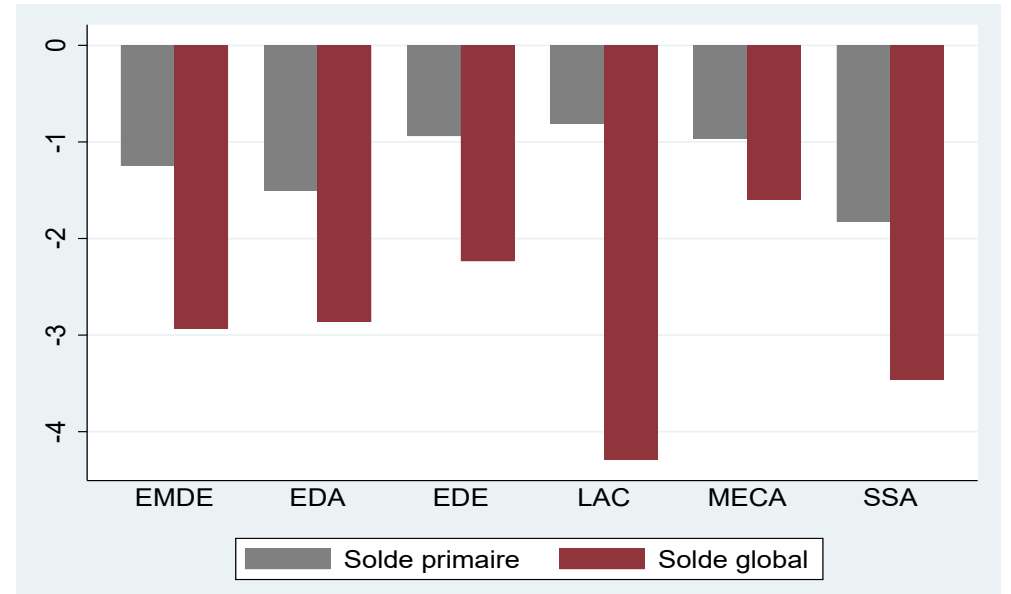

Notes: Data and classifications are from the International Monetary Fund's World Economic Outlook database. EMDE = Emerging Markets and Developing Economies, $\mathrm{EDA}=$ Emerging and Developing Asia, EDE = Emerging and Developing Europe, $\mathrm{LAC}=$ Latin America and the Caribbean, MECA = Middle East and Central Asia, $\mathrm{SSA}=$ Sub-Saharan Africa.

To better assess the sustainability of fiscal deficits in emerging markets and developing economies, it is above all important to know the structural determinants. Indeed, although the initial level of public debt influences the health of public finances, it is far from the only source of overall budget deficits. The fiscal balance is the consequence of various macroeconomic, political, demographic, institutional 
and social factors. Since the early 1980s, several empirical studies have focused on the determinants of public deficits (see, among others, Morrison, 1982; Roubini and Sachs, 1989; Roubini, 1991; Woo, 2003a; Tujula and Wolswijk, 2004; Steiner, 2017). Although some of these studies involve developing countries and emerging economies (Morrison, 1982; Roubini, 1991 and Woo, 2003a), the sample of these countries is often limited due to data availability over the study period. Furthermore, the determinants are often chosen on a subjective basis and vary widely depending on the study. While these studies meet their own objectives, it seems important to present a broader empirical view of the factors explaining public deficits.

This study aims to identify the robust structural determinants of public deficits in emerging and developing countries. To this end, we rely on a relatively large number of potential determinants of budget deficits highlighted by previous studies. In order to deal with the problem of model uncertainty raised by this multitude of potential explanatory variables and the absence of an integral theoretical model of the budgetary balance, we use Sala-i-Martin (1997)'s Extreme Bound Analysis. This method makes it possible to identify the most important structural determinants of budget deficits by starting out from a large number of potential determinants and performing thousands of alternative regressions. Our sample consists of 110 emerging and developing countries over the period 1998-2017. Our study contributes to the literature on the structural determinants of fiscal deficits. It provides a more complete view by examining the robust determinants of overall and structural budget balances. In addition, our study is based on a larger sample and more reliable data than previous studies on emerging and developing countries.

The results indicate that external shocks, the debt ratio, financial development, the level of democracy and government control over expenditures are robustly associated with fiscal deficits. Public deficits are lower in countries which provide better stability of public expenditure in the face of revenue instability and which are less exposed to negative external shocks. In contrast, fiscal deficits increase with the debt ratio, financial development and the level of democracy. Although to a lesser extent, budget deficits also depend on the exchange rate regime, the political system and the level of development. The importance of external shocks in the explanation of fiscal deficits argues for more diversification of developing economies in order to mitigate the impact of negative shocks, particularly in countries whose public finances are heavily dependent on trade-related tax revenues.

The rest of the paper is structured as follows. Section 2 reviews the potential sources of fiscal deficits. Section 3 presents our empirical strategy and describes the data. In Section 4, we present and comment on the regression results. We perform some sensitivity tests in Section 5 and Section 6 concludes the paper. 


\section{Potential sources of fiscal deficits}

Previous empirical studies have highlighted several determinants of (structural) budget deficits. However, these determinants and their importance differ considerably between studies. In this section, we group the potential sources of budget deficits into five categories: the macroeconomic environment, demographic factors, the quality of institutions, political pressures and social polarization and fragmentation.

\subsection{Macroeconomic environment}

The macroeconomic environment plays a decisive role in the fiscal performance of developing countries. It is characterized by several variables, each as important as the others.

External shocks. These are potentially an important source of structural fiscal performance in developing countries. Public finances in these countries are considerably influenced by changes in export and import prices, whether through the profits of exporting public enterprises or through import duties and export taxes (Woo, 2003a). These external shocks increase with the degree of trade openness and the terms of trade. Combes and Saadi-Sedik (2006) show that trade openness increases a country's exposure to external shocks and thus reinforces the negative impact of terms-of-trade instability on fiscal balances. Positive external shocks are expected to be associated with budget surpluses, while negative shocks are associated with budget deficits.

Instability and growth in government revenues. Affecting developing countries more strongly, the instability of government revenue is considered by Morrison (1982) as a structural determinant of budget deficits. It can have negative consequences on public investment (Ebeke and Ehrhart, 2012) and therefore on growth. Countries facing higher volatility in government revenues may have larger government deficits, to the extent that some government spending is incompressible or socially difficult to reduce (Morrison, 1982). In addition to instability, growth in government revenue (excluding inflation) could influence countries' structural budgetary performance. Indeed, countries with stronger growth in real government revenue are likely to achieve a higher fiscal performance than those with weak revenue growth (Morrison, 1982). However, such an assumption is subject to slower growth in public spending in countries with strong growth in government revenue.

Level of development and economic growth. Theoretically, low-income countries face larger budget deficits as they face greater pressure from basic public spend- 
ing (education, health, basic infrastructure) as they struggle to mobilize public revenues as well as private savings. Thus, public finances should improve with the level of economic development which is generally accompanied by a greater capacity to mobilize public revenues. In addition to the level of development, real GDP growth is also a determinant of the budget deficit, although it is less likely to affect its structural level. Indeed, the automatic stabilizer mechanism requires government revenues and the budget balance to deteriorate during a recession and improve during an expansion. These results have been established by several empirical studies (see among others, Morrison, 1982; Roubini and Sachs, 1989; Woo, 2003a; Steiner, 2017).

Inflation rate. The real effect of inflation on the fiscal balance remains ambiguous. However, its inclusion among the determinants of fiscal deficits is justified for several reasons. On the one hand, inflation erodes the real value of nominal public debt. On the other hand, it leads to higher nominal interest payments and lower real revenues (Woo, 2003a). In addition, if income taxes are not indexed to inflation, the latter can lead to an improvement in budgetary performance through the positive effect of the sliding of tax brackets. The inclusion of inflation as a potential determinant of budget deficits is also justified under the assumption that public authorities adapt their budgetary policies to respond to problems of loss of external competitiveness induced by high inflation (Tujula and Wolswijk, 2004).

Public debt and real interest rate. These two variables are considered to be key determinants of budget deficits. Public debt has a mechanical effect on the overall budget balance. Indeed, for a given interest rate level, countries with a higher debt level are more prone to budget deficits because of higher debt services. However, it is also possible to imagine that the level of debt serves as an automatic stabilizer in the sense that highly indebted countries would tend to apply more restrictive fiscal policies in order not to jeopardize public finances (Steiner, 2017). But as these policies could have adverse effects on growth, they could lead to an increase in the budget deficit in the long term. Like the public debt ratio, the interest rate can affect the budget deficit through debt service. Countries that go into debt at higher interest rates are likely to run larger budget deficits. But it is also plausible that governments paying higher interest will be forced to generate future surpluses to meet their inter-temporal budget constraint. The effect of the interest rate on budgetary performance therefore remains to be determined empirically.

Exchange rate regimes. Conventional wisdom dictates that countries which choose a fixed exchange rate regime or a monetary union have a more disciplined economic (budgetary and monetary) policy than the others (Tornell and Velasco, 1995). The typical argument is that under fixed exchange rate regimes, the adoption of lax fiscal policies or the quest for high wages by unions ultimately lead to 
balance of payments difficulties and therefore to the abandonment of anchoring, with considerable economic and political costs. To avoid such a situation, countries with fixed exchange rates should be more disciplined in their budgets by avoiding excessive spending. Logically, one would expect better budgetary performance from these countries. However, empirical studies are far from unanimous on this result (see Tornell and Velasco, 2000).

Level of financial development. The development of the domestic financial sector plays a decisive role in a nation's ability to finance its budget deficit. When local financial markets are developed, governments can more easily cover a deficit by issuing bonds and are less dependent on inflationary financing (Steiner, 2017). Empirical studies show that countries with developed financial markets are characterized by lower budget balances (see among others Woo, 2003a; Steiner, 2017).

\subsection{Demographic factors}

The situation of countries' public finance is linked to their demographic structure. Dependency ratios (of young and old) as well as the rate of urbanization are often cited among the determinants of budget deficits.

Dependency ratios. Dependency creates pressure on public spending, especially social spending. Countries with old-age dependency ratios spend more of their spending on social protection, such as pensions and health. Consequently, the higher the dependency ratio (people over 65 relative to the active population), the larger the budget deficit. The same reasoning applies for the dependency of young people (people under 15). Woo (2003a) and Steiner (2017) show that developing countries with higher old-age dependency ratios also have higher fiscal deficits.

The urbanization rate. As the urban population is relatively easier to tax than the rural population, particularly in developing countries where little or no rural activity is recorded, countries with high rates of urbanization are likely to have better fiscal performance (Edwards and Tabellini, 1991).

\subsection{Quality of institutions}

Fiscal performance in developing countries depends on the quality of their institutions. In general, countries that build strong institutions tend to achieve lower budget deficits because they create the conditions for economic stability and higher tax collection. The quality of institutions can be measured by several variables. 
Quality of governance. Good governance should enable developing countries to improve their fiscal performance and reduce their dependence on official development assistance to finance their budget deficits. Several studies link the quality of governance to the budget deficit. Woo (2003a) stresses that efficient institutions are associated with higher growth and can positively impact public finances. An efficient tax revenue collection mechanism should improve the budget balance. Similarly, Woo (2003a) argues that when conflict management institutions are well established and function well enough to remove conflicts of interest between different groups, the potentially negative effect of social polarization on public finances is significantly reduced. According to this author, institutional variables such as the effectiveness of public management, control of corruption and the rule of law are good measures of the quality of fiscal institutions. Thus, an improved performance by these variables helps to reduce budget deficits. Collier (2000) indicates that, due to corruption, many companies can benefit from state subsidies, even when they are on the verge of bankruptcy; this is likely to worsen the budget deficit. Corruption often operates through its effects on increasing public spending (Benfratello, Monte, and Pennacchio, 2018). Liu, Moldogaziev, and Mikesell (2017) show that a high level of corruption leads to higher levels of global imbalances and public debt in a country.

Level of democracy. This is recognized as one of the determinants of fiscal performance in emerging and developing countries. Several studies show the existence of a political cycle in both young and more experienced democracies. This cycle consists of the implementation of more expansionary policies (increased public spending and/or lower taxes) during electoral periods (see Brender and Drazen, 2005 and de Haan, 2014). However, Brender and Drazen (2005) argues that the effect of the electoral cycle is more significant in young democracies. Roubini and Sachs (1989) maintain that political and economic forces in democratic countries are responsible for large and sustained public deficits. According to them, the difficulties of political management in coalition governments are favourable to persistent public deficits.

Government control over expenditures and the size of government. Several institutional and structural factors can influence the ability of governments to control spending, including the efficiency of the budget system, coordination between the planning and finance ministries and the share of recurrent spending in total spending (Morrison, 1982). When governments are unable to control spending, they will tend to experience relatively large budget deficits. In addition to spending control, strong government intrusion into economic life - through taxation, spending and other types of intervention - hampers economic freedoms. Morrison (1982) considers that the size of government is generally a source of structural deficits in 
public finances. Countries with a relatively higher degree of government involvement are often subject to greater spending pressures. In addition, a relatively large size of the public sector is likely to be positively related to an increase in government involvement in production and increased government control over economic variables such as prices and interest rates. However, experience shows that public enterprises in developing countries have poor public financial management and are not efficient in making the most appropriate investments in terms of comparative advantage. Similarly, inflationary pressures induced by government controls have negative repercussions on the State budget, particularly through the subsidies needed to keep food prices low. This view is not unanimously supported in the literature. For example, Ram (1989) indicates that a greater state presence in the economy is a source of economic performance and positive externalities. The recent literature confirms this lack of consensus, though the majority of studies show that a larger public sector hinders economic growth and is detrimental to public finances (Kim, Wu, and Lin, 2018).

\subsection{Political pressures}

There are a number of policy factors that can lead to or aggravate structural budget deficits.

Political fragmentation. This reflects the political capacity of governments to implement fiscal adjustments more or less quickly in the event of adverse exogenous shocks. Alesina and Drazen (1991) show that coalition or minority governments often face more persistent budget deficits following adverse exogenous shocks as different political parties have difficulty agreeing on the "key" to sharing the burden of adjustment. Roubini and Sachs (1989) note a trend towards larger budget deficits in countries characterized by the presence of many political parties in a ruling coalition in industrialized countries. A similar result is highlighted by Volkerink and Haan (2001) on a sample of 22 OECD countries. However, Woo (2003a) fails to establish a significant relationship between policy fragmentation and fiscal performance across a wider range of developed and developing countries.

Electoral pressures. These often push governments to be more generous. Indeed, in order to increase their chances of re-election, governments are more inclined to spend more and tax less during election periods. Thus, countries facing a high occurrence of elections are likely to experience larger structural deficits. Schuknecht (2000) shows that the main driver of expansionary fiscal policies around elections in developing countries is increased public spending. Ebeke and Ölcer (2013) point out that during election years, public consumption increases considerably and induces 
large public deficits. Moreover, according to them, post-electoral budgetary adjustment is made to the detriment of public investment, which increases the economic cost of opportunistic electoral policies.

The political system, political maturity and duration in office of the chief executive. Fiscal performance may differ across policy regimes. Persson and Tabellini (1999) shows that presidential regimes are less redistributive and usually involve smaller governments. Similarly, as they enjoy greater independence and centralized authority, presidential regimes are better able to adjust to possible fiscal imbalances than parliamentary regimes (Shugart and Carey, 1992). According to Woo (2003a), although presidential regimes tend to have better budgetary performance than parliamentary regimes, this result is not statistically significant. In addition to the political system, the maturity or age of political parties can have an influence on fiscal performance. The more experienced political parties are, the more influential they are in determining the trajectory of national budgets voted in the assembly. Thus, mature political parties could be a blocking factor, for example when the government wishes to make rapid adjustments to cope with unfavourable economic conditions. Finally, the duration in power of the head of the executive can be perceived as the capacity of the power to resist adverse political forces. Under these conditions, the tax trajectory would be less constrained by competing political parties. Consequently, it is possible that budget deficits will be more pronounced in countries with greater political alternation.

\subsection{Social polarization and fragmentation}

Real or perceived income inequality, social fragmentation and the size of the informal economy can durably affect the health of countries' public finances.

Income inequality. The effect of income inequality on budget deficits was empirically studied for the first time by Woo (2003b). This author shows that countries with higher income inequality have higher budget deficits. The underlying idea is that, in these countries, the incentives to increase redistributive spending are higher. This study draws on the works of Alesina and Rodrik (1994), Persson and Tabellini (1994) and Clarke (1995), which show that income inequality is harmful to economic growth. According to them, high levels of inequality provoke major conflicts over redistribution issues and induce governments to raise taxes to compensate for transfer expenditures. This negatively affects the rate of return on private assets, restricting capital accumulation and growth.

Social divisions. In additional to income inequality, social fragmentation (ethnic 
and religious) is also a source of conflict, leading governments to implement procyclical fiscal policies that are unfavourable to economic growth (see Woo, 2009). Therefore, it can be assumed that the most socially polarized countries have larger budget deficits as shown in Woo (2003a).

Informal activity. Insofar as it escapes the control of government authorities and given its scale in certain emerging and developing countries, the informal economy constitutes a considerable shortfall for public finances. The countries most affected by this problem suffer huge losses in tax revenues and are likely to run larger budget deficits. Elgin and Uras (2013) show, for example, that a larger informal sector is associated with higher public debt, higher interest rates paid on sovereign debt and a higher probability of sovereign default.

\section{Empirical strategy and data}

\subsection{Econometric strategy}

In order to study the structural determinants of public deficits in developing countries, we essentially use a cross-sectional analysis in which the variable to be explained is the average of the fiscal balance over the period 1998-2017. This approach is quite common in the literature (see, among others, Morrison, 1982; de Haan and Sturm, 1997; Woo, 2003a) and allows us to some extent to purge cyclical components of the fiscal balance that could be explained by transitory shocks. The cross-sectional approach thus makes it possible to focus on the factors explaining the structural differences in fiscal deficits between countries.

Empirical divergences on the structural determinants of public deficits and the absence of a consensual theoretical model raise the issue of model uncertainty. To deal with this issue, we use the Extreme Bound Analysis (EBA) initially developed by Leamer (1985) and completed by Sala-i-Martin (1997). This method is well known in the literature and is often used to identify the robust determinants of a dependent variable of interest when the problem of model uncertainty arises.

Roughly speaking, by considering a set of potential determinants $Z$, the EBA consists in estimating thousands of alternative regressions in order to determine which variables of this set are robustly associated with the fiscal balance. All regressions have the fiscal balance as the dependent variable and contain a set of standard explanatory variables $F$ which are included in each of these regressions. These variables are those for which there is some consensus in previous theoretical or empirical 
studies. In addition to the $F$ variables, each regression includes a different subset $E$ in the potential determinants $Z$. The convention in the literature is that $F$ variables should be defined as free variables and $Z$ variables as doubtful variables. When subsets in doubtful variables $Z$ require particular interest, they are declared as "focus" variables. After all the regressions have been carried out, the doubtful variables are declared "robust" when they appear statistically significant in a very significant proportion. Otherwise, they are considered "fragile".

Formally, to find out if a variable of interest $v \in Z$ robustly explains the fiscal balance $(F B)$, a set of regression models of the following form is estimated :

$$
F B=\alpha_{\tau}+\beta_{\tau} v+\lambda_{\tau} F+\vartheta_{\tau} E_{\tau}+\epsilon
$$

where $\tau$ is the index of each regression model, $F$ is the set of free (or "consensual") variables that will be included in each regression model, $E_{\tau}$ is a vector of $k$ variables from the set $Z$ of doubtful variables, and $\epsilon$ is the error term. Equation 1 is estimated for each of the $T$ possible combinations of $E_{\tau} \subset Z$. After each regression, the estimated coefficients $\widehat{\beta}_{\tau}$ of the variable of interest $v$ and the corresponding standard deviations $\widehat{\sigma}_{\tau}$ are collected and stored for calculations that will then determine whether $v$ is robust or fragile.

In practice, two generations of EBA exist. The first generation of EBA is the one proposed by Leamer (1985). This is qualified as "exigent" or "rigid" because it focuses on the lower and upper extreme bounds of the coefficients, defined for each regression, as the minimum and maximum values of $\widehat{\beta}_{\tau} \pm \kappa \widehat{\sigma}_{\tau}$ where $\kappa$ is the critical value for the requested confidence level (usually 1.96 for a conventional confidence level of 95\%). Therefore, a variable of interest is declared to be robust only if its estimated extreme coefficients keep the same sign in all regressions. In other words, a robust variable is a variable whose estimated coefficients are statistically different from zero in all the regressions performed. A single exception is sufficient to declare the variable fragile. This binary approach by Leamer (1985) is considered too restrictive and characterized by a low probability of finding a robust variable. Ultimately, Learner's EBA is not very informative. To overcome this limitation, Sala-i-Martin (1997) proposes a second generation of EBA which is qualified as "flexible" since it considers the entire distribution of regression coefficients and not only the lower and upper extreme bounds. Therefore, we use the more informative approach proposed by Sala-i-Martin (1997) in this study. 


\subsection{Sala-i-Martin (1997)'s EBA and Hlavac (2016)'s rou- tines}

Briefly, the EBA approach proposed by Sala-i-Martin (1997) implies assigning a certain level of confidence - of value CDF (0) - to each variable, indicating its level of robustness. This value corresponds to the proportion of the variable's cumulative distribution that lies on each side of zero. Therefore, a variable is more robust the greater the proportion of its estimated coefficients are on the same side of zero. To allow for greater flexibility, the author proposes two variants for his analysis of the extreme bounds. One considers a normal model in which the estimated coefficients are assumed to follow a normal distribution, and the other relies on a generic model in which no particular distribution is assumed for the regression coefficients.

Estimating the normal model involves calculating the weighted mean of the regression coefficients $\widehat{\beta}_{\tau}$ and of the variances $\widehat{\sigma}_{\tau}^{2}$ as follows:

$$
\begin{gathered}
\bar{\beta}=\sum_{\tau=1}^{T} w_{\tau} \widehat{\beta}_{\tau}, \\
\bar{\sigma}^{2}=\sum_{\tau=1}^{T} w_{\tau} \widehat{\sigma}_{\tau}^{2}
\end{gathered}
$$

where $w_{\tau}$ refers to the weights applied to the results of each estimated model. According to Sala-i-Martin, applying weights allows more weight to be given to regressions that are more likely to be the "true" model, assuming that the fit of model $\tau$ is an indication of its probability of being the "true" model. Once the $\bar{\beta}$ and the $\bar{\sigma}^{2}$ are known, Sala-i-Martin calculates $\operatorname{CDF}(0)$ - that is, the cumulative density function evaluated at zero - based on the assumed normal distribution of regression coefficients, such that $\beta \sim \mathcal{N}\left(\bar{\beta}, \bar{\sigma}^{2}\right)$.

For the generic model, the cumulative density function of each regression model is estimated separately. Then Sala-i-Martin groups them into an aggregated CDF $(0)$ which is used as a measure of the robustness of the variable of interest. To obtain an individual $\operatorname{CDF}(0)$, denoted $\phi_{\tau}\left(0 \mid \widehat{\beta}_{\tau}, \widehat{\sigma}_{\tau}^{2}\right)$, for each estimated regression model, he uses the sampling distribution of the regression coefficient $\widehat{\beta}_{\tau}$. Then, the overall $\operatorname{CDF}(0)$ for $\beta$ is calculated as the weighted mean of all individual $\operatorname{CDF}(0) \mathrm{s}$ :

$$
\Phi(0)=\sum_{\tau=1}^{T} w_{\tau} \phi_{\tau}\left(0 \mid \widehat{\beta}_{\tau}, \widehat{\sigma}_{\tau}^{2}\right)
$$

In both types of model, Sala-i-Martin assigns weights that are proportional to the integrated likelihood to give greater weight to models that provide a better fit. Thus, 
we get:

$$
w_{\tau}=\frac{A_{\tau}}{\sum_{j=1}^{T} A_{j}}
$$

where $A_{j}$ is the measure of the goodness of fit of model $j$, here its integrated likelihood.

Although the EBA method is old and widely used, its appeal in empirical studies has continued to grow and the new routines developed on its use by Hlavac (2016) make it even more attractive. Indeed, unlike the existing routines, those proposed by Hlavac (2016) offer several advantages including, among others, the estimation of robust standard deviations and the possibility of alleviating concerns about multicollinearity and the conceptual overlap of the variables studied.

\subsection{Data}

The study covers 110 emerging and developing countries over the period 1998-2017 ${ }^{1}$. Given the number of variables considered, several sources of data were used.

For the most part, the macroeconomic variables are from the databases of the International Monetary Fund (IMF) and the World Bank (WB). The external shock variable is calculated by multiplying the degree of openness (imports + exports as a percentage of GDP) by the change in the terms of trade as defined by Morrison (1982). These two variables come from the WB's World Development Indicators (WDI) database. This is also the case for the economic growth rate, the real interest rate and the financial development variable measured by the amount of credit extended by banks to the private sector as a percentage of GDP. The fiscal balance (as a percentage of GDP), inflation rate, public debt ratio, government revenue and expenditure are taken from the IMF's World Economic Outlook (WEO) database. Like Morrison (1982), we measure the instability of government revenues by an index $E_{r} / M_{r}$ where $E_{r}$ is the standard deviation of residuals from the regression of government revenues on a time trend over the period 1998-2017, and $M_{r}$ is the mean value of revenues over the same period. Real GDP per capita at purchasing power parity is from the Penn World Tables (PWT9.1).

The demographic variables (urbanization rate and dependency ratio) are from the WDI. The dependency ratio is calculated as the number of non-active people (young people under the age of $15+$ people aged 65 and over) divided by the active population. The country's dependency ratio is divided by the world dependency ratio to obtain the relative dependency ratio.

\footnotetext{
${ }^{1}$ See the list of countries in Annex A-1.
} 
With regard to the quality of institutions, we use the Polity2 index from the POLITY IV database as a measure of the level of democracy. It is designed on the basis of three essential and interdependent elements: the presence of institutions and procedures through which citizens can express effective preferences about alternative policies and leaders; the existence of institutionalized constraints on the exercise of power by the executive; and the guarantee of civil liberties to all citizens in their daily lives and in acts of political participation. Countries have a democracy index ranging from -10 (strongly autocratic) to +10 (strongly democratic). The indices of political stability, government effectiveness and control of corruption are from the Worldwide Governance Indicators (WGI) database produced by Kaufmann and Kraay. These indices are continuous variables ranging from -2.5 (weak performance) to +2.5 (strong performance). The size of government reflects the extent to which government spending, taxation, and the size of government-controlled enterprises increase, to which government decision-making is substituted for individual choice and to which economic freedom is reduced. This variable comes from the Fraser Institute's Economic Freedom of the World (EFW) database. Government control over expenditures measures the capacity of public authorities to control public expenditure in a situation of large variation in public revenue. Following Morrison (1982), we measure it by the ratio of government expenditure instability to government revenue instability over the period 1998-2017, with both instability indices being defined as above.

Regarding the political pressure variables, they all come from the Database of Political Institutions (DPI) of Scartascini, Cruz, and Keefer (2018). Political fragmentation measures the probability that two deputies picked at random from the legislature will be of different parties. The occurrence of elections is the total number of legislative and presidential elections taking place over the study period relative to the length of the study period. The political system is a binary variable that takes the value 1 if the political system is presidential and 0 otherwise. Duration in office measures the average number of years the chief executive remains in office. Political maturity is measured by the average age of political parties in the country.

The last category of variables concerns social polarization and fragmentation. Income inequality is taken from the World Income Inequality Database (WIID) and is measured using the Gini index, a measure of the distribution of income in a society. The variable of shadow economy - the estimated output of all economic activities which are hidden from official authorities for monetary, regulatory, and institutional reasons - as a percentage of GDP, is constructed by Medina and Schneider (2018). Measures of ethnic and religious fragmentation are taken from the database of Alesina, Devleeschauwer, Easterly, Kurlat, and Wacziarg (2003). Descriptive statistics on all variables used are presented in Table 1. 
Table 1: Descriptive statistics

\begin{tabular}{|c|c|c|c|c|c|}
\hline VARIABLES & Observation & Mean & Standard deviation & Minimum & Maximum \\
\hline \multicolumn{6}{|l|}{ Dependent variable } \\
\hline Fiscal balance (\% GDP) & 110 & -2.266 & 2.711 & -11.546 & 7.164 \\
\hline External shocks & 108 & 1.074 & 2.162 & -1.568 & 13.098 \\
\hline Economic growth & 110 & 4.291 & 2.051 & 0.602 & 12.048 \\
\hline Financial development & 110 & 44.404 & 33.885 & -13.334 & 177.534 \\
\hline Log (real GDP per capita) & 108 & 8.646 & 1.063 & 6.436 & 11.432 \\
\hline Pegged currency system & 110 & 0.500 & 0.502 & 0.000 & 1.000 \\
\hline Public debt (\% GDP) & 109 & 52.670 & 27.076 & 1.145 & 154.939 \\
\hline Real interest rate & 91 & 7.144 & 6.376 & -6.891 & 40.720 \\
\hline Instability of government revenues & 110 & 2.966 & 2.185 & 0.411 & 10.714 \\
\hline Real growth of government revenues & 110 & 0.380 & 8.840 & -55.096 & 15.653 \\
\hline Level of democracy & 100 & 3.190 & 5.541 & -10.000 & 10.000 \\
\hline Political stability & 110 & -0.311 & 0.817 & -2.220 & 1.241 \\
\hline Government effectiveness & 110 & -0.321 & 0.671 & -1.648 & 1.334 \\
\hline Control of corruption & 110 & -0.364 & 0.685 & -1.568 & 1.466 \\
\hline Size of government & 102 & 6.697 & 1.061 & 4.030 & 9.441 \\
\hline Government control over expenditures & 110 & 1.252 & 0.541 & 0.394 & 3.675 \\
\hline \multicolumn{6}{|l|}{ Political pressures } \\
\hline Political fragmentation & 108 & 0.536 & 0.210 & 0.000 & 0.924 \\
\hline Occurrence of elections & 108 & 0.258 & 0.106 & 0.000 & 0.500 \\
\hline Political system & 108 & 0.691 & 0.451 & 0.000 & 1.000 \\
\hline Duration in office & 108 & 8.129 & 7.148 & 2.250 & 37.500 \\
\hline
\end{tabular}

\section{Empirical results}

Since model uncertainty is particularly high in the analysis of public deficits due to the lack of solid theoretical foundations, we do not a priori consider any variable as "free". In other words, all potential determinants of fiscal deficits are considered to be doubtful variables. This is a way to put all the potential determinants on the same level and to test the robustness of each of them without presupposition. However, as in most cross-sectional studies on a large sample, regional dummy variables $^{2}$ are included in all regressions to capture heterogeneity between regions.

\footnotetext{
${ }^{2}$ These variables are defined according to the World Bank classification: East Asia and the Pacific (EAP), Europe and Central Asia (ECA), Latin America and the Caribbean (LAC), Middle East and North Africa (MENA), Sub-Saharan Africa (SSA).
} 
These are therefore the standard $F$ explanatory variables in Equation 1. Furthermore, as the conceptual overlapping of certain variables can raise concerns about multicollinearity, we overcome this problem by using the EBA routine developed by Hlavac (2016), which allows the specification of mutually exclusive sets of variables. This is particularly the case for the level of democracy, political stability, government effectiveness and control of corruption. In other words, these four variables do not intervene together in the same regression but rather alternately.

\subsection{Robust determinants of the fiscal balance}

The results of the cross-section regressions from Equation 1 in which the fiscal balance is the dependent variable are shown in Table 2. The first two columns are respectively the weighted mean of the regression coefficients and the corresponding weighted standard deviation, as defined in Equations 2 and 3. The third column indicates the proportion in which each estimated coefficient appears significantly different from zero in the set of regressions involving the associated variable. Finally, for completeness, the last four columns present the aggregate cumulative density function (CDF) of the regression coefficients based on the two models - normal and generic - defined by Sala-i-Martin (1997). Rather than focusing on the aggregate cumulative density function, we mainly examine the proportion in which the estimated coefficients are significantly different from zero. Three levels of robustness are defined to facilitate the interpretation of the results. A variable is declared to be "robust" in the explanation of the fiscal balance if its coefficient appears significantly different from zero in at least $90 \%$ of the regressions in which it is involved. When this proportion is between $70 \%$ and $90 \%$, the variable is considered to be "moderately robust". Below 70\%, the variable is "not robust".

The results show that external shocks, financial development, the public debt ratio, the level of democracy and government control over spending are the most robust determinants of the fiscal balance. In particular, public deficits are higher in countries with a higher level of debt, a more developed financial sector and better democracy. Likewise, countries facing larger negative external shocks have larger budget deficits. Furthermore, the less governments are able to control public spending, the larger the budget deficits. While the results appear intuitive for external shocks, public debt and government control over expenditures, this is less the case for the level of democracy. Indeed, one might think that the least democratic countries are more spendthrift and less efficient in collecting public revenues, for several reasons including corruption, embezzlement and tax evasion. However, some studies show that "young" democracies are often more spendthrift and use fiscal policy more often for electoral purposes (see among others Brender and Drazen, 2005 and de Haan, 2014). 
Regarding the role of the financial sector, our results are consistent with those of Woo (2003a) and Steiner (2017), indicating that countries with a more developed internal financial sector tend to further deepen their budget deficit given that the latter is more easily financed.

From these results, it also emerges that the exchange rate regime, the level of development and the political system are important determinants of fiscal balance. They can be considered as moderately robust variables. Low-income countries are more exposed to budget deficits given the relatively large weight of basic expenditure. Concerning the political system, our results are in line with those of Persson and Tabellini (1999) who show that presidential systems have better fiscal performances because they are less redistributive and generally involve smaller governments. It is important to note that for all the variables identified, at least $95 \%$ of the cumulative density function (CDF) of the estimated coefficients is on the same side of zero, whether we consider the normal model or the generic model. This reflects their importance in explaining fiscal deficits.

Figure 2 shows the cumulative density functions (CDFs) of the estimated coefficients for a set of variables, essentially those that are most significant. The signs of the coefficients associated with each of these variables as well as the distribution of these coefficients are clearly highlighted. Thus, over a large number of regressions, all or almost all of the estimated coefficients show a positive sign for some variables (external shocks, government control over expenditures, pegged currency, the presidential political system) and a negative sign for others (public debt ratio, level of democracy, financial development). The former contribute to the improvement of the fiscal balance while the latter accentuate fiscal deficits. 
Table 2: Determinants of the fiscal balance

\begin{tabular}{|c|c|c|c|c|c|c|c|}
\hline \multirow[b]{2}{*}{ Variables } & \multirow[b]{2}{*}{ Coef. (Wgt Mean) } & \multirow[b]{2}{*}{ S.E. (Wgt Mean) } & \multirow[b]{2}{*}{ Pct(signif. $\neq 0$ ) } & \multicolumn{2}{|c|}{ Normal model $(\mathrm{N})$} & \multicolumn{2}{|c|}{ Generic model $(\mathrm{G})$} \\
\hline & & & & $\operatorname{CDF}(\beta<=0)$ & $\operatorname{CDF}(\beta>0)$ & $\operatorname{CDF}(\beta<=0)$ & $\operatorname{CDF}(\beta>0)$ \\
\hline External shocks & 0.402 & 0.118 & 96.23 & 0.065 & 99.94 & 0.609 & 99.39 \\
\hline Instability of gov. revenues & -0.006 & 0.009 & 13.27 & 74.11 & 25.89 & 70.21 & 29.79 \\
\hline Economic growth & 0.100 & 0.162 & 0.569 & 27.18 & 72.82 & 30.73 & 69.27 \\
\hline Financial development & -0.040 & 0.013 & 91.57 & 99.88 & 0.120 & 99.13 & 0.872 \\
\hline Inflation rate & 0.007 & 0.017 & 10.84 & 34.30 & 65.70 & 35.49 & 64.51 \\
\hline Log (real GDP per capita) & 1.047 & 0.358 & 78.40 & 0.199 & 99.80 & 4.490 & 95.51 \\
\hline Currency anchoring & 0.965 & 0.427 & 70.32 & 1.231 & 98.77 & 3.643 & 96.36 \\
\hline Public debt (\% GDP) & -0.053 & 0.010 & 100.0 & 100.0 & 0.000 & 100.0 & 0.000 \\
\hline Real interest rate & -0.019 & 0.028 & 9.431 & 75.52 & 24.49 & 68.56 & 31.44 \\
\hline Real growth of gov. revenues & -0.002 & 0.021 & 2.249 & 54.09 & 45.91 & 55.26 & 44.74 \\
\hline Dependency ratio & -5.057 & 2.387 & 53.84 & 98.09 & 1.907 & 91.41 & 8.591 \\
\hline Urbanization rate & 0.031 & 0.016 & 49.04 & 3.250 & 96.75 & 7.717 & 92.28 \\
\hline Political stability & 0.110 & 0.345 & 8.789 & 37.66 & 62.34 & 42.72 & 57.28 \\
\hline Government effectiveness & -0.368 & 0.443 & 24.32 & 79.22 & 20.79 & 66.95 & 33.05 \\
\hline Corruption control & -0.050 & 0.442 & 7.422 & 54.40 & 45.60 & 53.70 & 46.30 \\
\hline Level of democracy & -0.229 & 0.068 & 97.22 & 99.96 & 0.041 & 99.77 & 0.234 \\
\hline Size of Government & -0.402 & 0.310 & 9.644 & 90.03 & 9.968 & 87.38 & 12.62 \\
\hline Gov. control over expenditures & 0.095 & 0.025 & 98.54 & 0.012 & 99.99 & 0.305 & 99.70 \\
\hline Political fragmentation & -1.246 & 1.400 & 10.53 & 80.94 & 19.06 & 74.47 & 25.53 \\
\hline Election occurrence & -4.217 & 2.628 & 40.32 & 94.45 & 5.555 & 86.92 & 13.08 \\
\hline Political system & 1.280 & 0.575 & 69.47 & 1.431 & 98.57 & 2.784 & 97.22 \\
\hline Years in office of the chief executive & 0.080 & 0.041 & 66.76 & 2.891 & 97.11 & 9.428 & 90.57 \\
\hline Average age of political parties & -0.006 & 0.007 & 1.957 & 78.32 & 21.68 & 73.39 & 26.61 \\
\hline Income inequality & 0.031 & 0.038 & 6.299 & 20.88 & 79.12 & 25.92 & 74.08 \\
\hline Ethnic fragmentation & 0.786 & 1.201 & 0.605 & 25.86 & 74.14 & 28.57 & 71.43 \\
\hline Size of shadow economy & 0.033 & 0.025 & 19.82 & 10.07 & 89.93 & 15.43 & 84.57 \\
\hline Religious fragmentation & -0.501 & 1.279 & 0.000 & 64.98 & 35.02 & 62.50 & 37.50 \\
\hline SSA & 2.335 & 0.953 & 75.28 & 0.783 & 99.22 & 4.476 & 95.52 \\
\hline $\mathrm{ECA}$ & 1.885 & 1.060 & 51.92 & 3.884 & 96.12 & 9.097 & 90.90 \\
\hline MENA & 1.386 & 1.470 & 7.824 & 17.68 & 82.32 & 22.95 & 77.05 \\
\hline EAP & 2.546 & 1.029 & 78.61 & 0.706 & 99.29 & 2.739 & 97.26 \\
\hline LAC & 1.843 & 0.950 & 54.09 & 2.742 & 97.26 & 7.576 & 92.42 \\
\hline Constant & -6.565 & 2.251 & 69.15 & 99.55 & 0.450 & 86.41 & 13.59 \\
\hline
\end{tabular}

Notes : Differences presented are robust to heteroskedasticity. The variance inflation factor (VIF) is set
variables are shown in bold, robust variables in bold and italics, and moderately robust variables in italics. 
Figure 2: Cumulative density function of the coefficients $\beta$
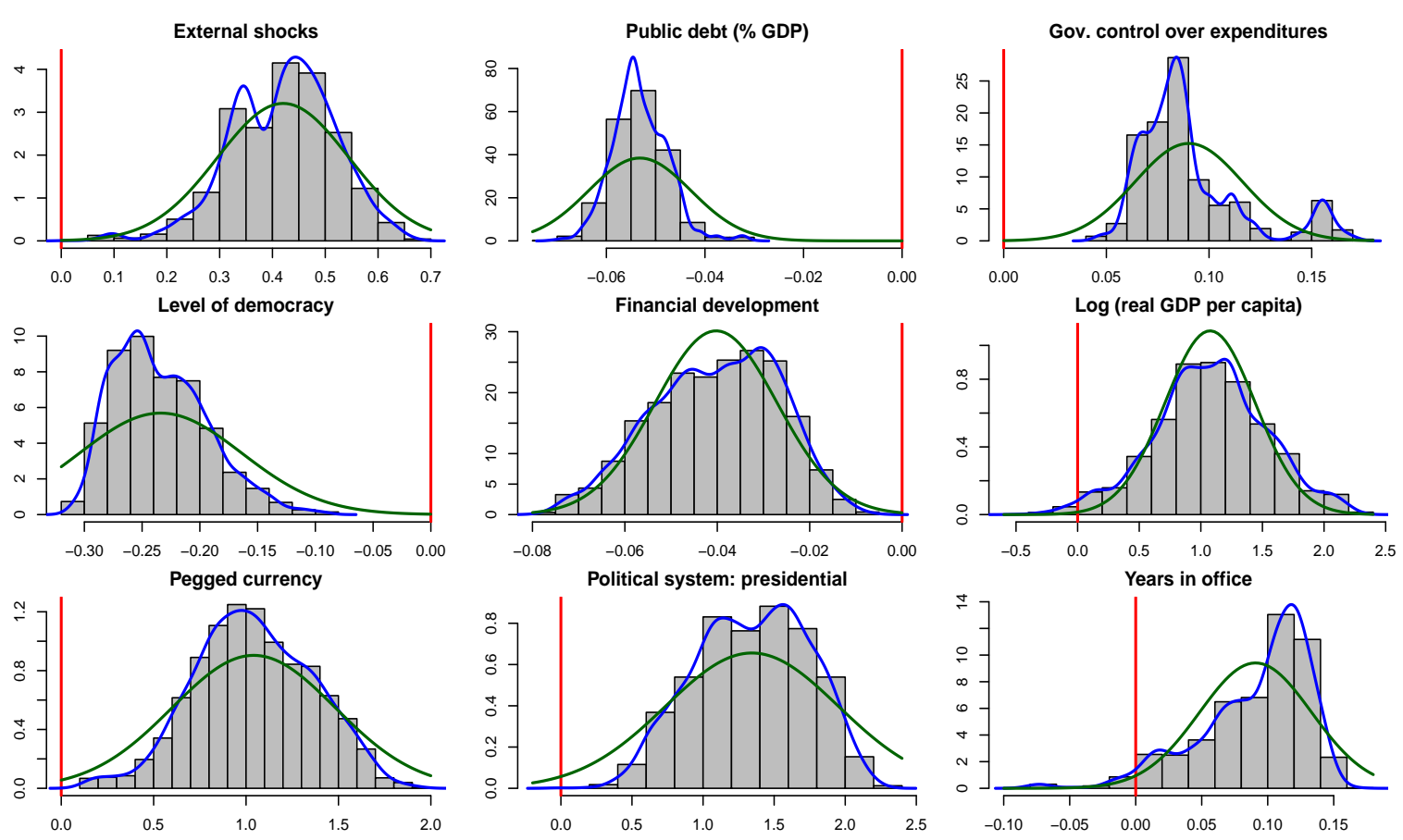

Notes: The magnitudes of the regression coefficients are on the horizontal axis. The vertical axis shows the corresponding probability density. The blue curve is the Kernel density curve and the green curve is a normal distribution. The vertical red line at zero indicates the value of the default coefficient under the null hypothesis.

\subsection{Robust determinants of structural fiscal balance}

Changes in a country's overall fiscal balance are guided both by discretionary (expansionary or restrictive) fiscal policy measures and by macroeconomic conditions. Unlike the overall budgetary balance, the structural fiscal balance is purged of the effects of the economic cycle. Consequently, the differences in the countries' structural budget balances mainly stem from their fundamental differences (economic, social and political). Thus, the structural determinants of the overall fiscal balance can be expected to be comparable with the determinants of the structural fiscal balance. Moreover, by relying on the average of the variables to study the structural determinants of the fiscal balance, we get closer to the structural fiscal balance since the effects of the cycle are generally annihilated. Therefore, it appears interesting, as a robustness test, to use the structural fiscal balance instead of the overall fiscal balance. However, unlike the overall fiscal balance, which is measured by international institutions (in particular the IMF and the WB) and for which data are available for emerging and developing countries, data on the structural fiscal balance (SFB) 
are very scarce for these countries due to measurement difficulties. Indeed, the calculation of SFB requires the availability of data on potential GDP. Such data are not available for most emerging and developing countries. Given the unavailability of data, we decide to calculate the structural fiscal balance of emerging and developing countries over the study period using the methodology of Fedelino, Horton, and Ivanova (2009). ${ }^{3}$

Table 3 reports the EBA results on the determinants of the structural fiscal balance. The regressions performed are the same as those whose results are summarized in Table 2, with the only difference that the dependent variable is now the structural budget balance and not the overall budget balance. These results are broadly similar to those on the determinants of the overall budget balance. Indeed, we obtain the same robust determinants as previously, namely external shocks, the public debt ratio, the level of democracy and government control over spending. Only financial development no longer appears in this category but whose proportion of significantly different coefficients remains high at $83 \%$. Likewise, the level of development, political system and to a lesser extent the exchange rate regime are moderately robust as before. They therefore play an important role in explaining structural deficits in developing countries.

Ultimately, the EBA applied to the structural budget balance leads to the identification of the same key determinants as those obtained in the analysis of the overall budget balance. Thus, the most important structural determinants in explaining budget deficits are external shocks, public debt, the level of democracy, government control over expenditures, the level of economic development, financial development, the political system, and the exchange rate regime. Only these explanatory variables have more than $95 \%$ of the cumulative density function of their estimated coefficients located to the right or to the left of zero, whatever the model considered (normal or generic), which testifies to the robustness of their sign and of their influence.

\footnotetext{
${ }^{3}$ See Appendix A-2.
} 
Table 3: Determinants of the structural fiscal balance

\begin{tabular}{|c|c|c|c|c|c|c|c|}
\hline \multirow[b]{2}{*}{ Variables } & \multirow[b]{2}{*}{ Coef. (Wgt Mean) } & \multirow[b]{2}{*}{ S.E. (Wgt Mean) } & \multirow[b]{2}{*}{ Pct(signif. $\neq 0$ ) } & \multicolumn{2}{|c|}{ Normal model $(\mathrm{N})$} & \multicolumn{2}{|c|}{ Generic model (G) } \\
\hline & & & & $\operatorname{CDF}(\beta<=0)$ & $\operatorname{CDF}(\beta>0)$ & $\operatorname{CDF}(\beta<=0)$ & $\operatorname{CDF}(\beta>0)$ \\
\hline External shocks & 0.393 & 0.120 & 95.37 & 0.092 & 99.91 & 0.708 & 99.29 \\
\hline Instability of gov. revenues & -0.010 & 0.009 & 32.85 & 85.26 & 14.75 & 77.56 & 22.44 \\
\hline Economic growth & 0.122 & 0.165 & 0.925 & 23.36 & 76.64 & 27.14 & 72.87 \\
\hline Financial development & -0.038 & 0.013 & 83.17 & 99.74 & 0.258 & 98.52 & 1.481 \\
\hline Inflation rate & 0.007 & 0.017 & 9.639 & 34.32 & 65.69 & 35.53 & 64.47 \\
\hline Log (real GDP per capita) & 1.024 & 0.359 & 77.94 & 0.250 & 99.75 & 4.705 & 95.30 \\
\hline Pegged currency & 0.940 & 0.428 & 66.09 & 1.455 & 98.54 & 3.973 & 96.03 \\
\hline Public debt (\% GDP) & -0.051 & 0.010 & 100.0 & 100.0 & 0.000 & 100.0 & 0.000 \\
\hline Real interest rate & -0.019 & 0.028 & 8.683 & 75.70 & 24.30 & 69.11 & 30.89 \\
\hline Real growth of gov. revenues & -0.002 & 0.021 & 1.566 & 53.46 & 46.54 & 54.68 & 45.32 \\
\hline Dependency ratio & -5.819 & 2.388 & 64.37 & 99.15 & 0.849 & 93.93 & 6.071 \\
\hline Urbanization rate & 0.036 & 0.017 & 64.02 & 1.484 & 98.52 & 5.433 & 94.57 \\
\hline Political stability & 0.096 & 0.346 & 7.764 & 39.16 & 60.84 & 44.11 & 55.89 \\
\hline Government effectiveness & -0.300 & 0.443 & 23.44 & 74.68 & 25.32 & 63.33 & 36.67 \\
\hline Corruption control & -0.045 & 0.442 & 6.445 & 54.04 & 45.96 & 53.37 & 46.63 \\
\hline Level of democracy & -0.233 & 0.067 & 98.05 & 99.97 & 0.032 & 99.82 & 0.185 \\
\hline Size of Government & -0.394 & 0.310 & 8.256 & 89.55 & 10.45 & 86.96 & 13.04 \\
\hline Gov. control over expenditures & 0.091 & 0.026 & 98.29 & 0.024 & 99.98 & 0.369 & 99.63 \\
\hline Political fragmentation & -1.600 & 1.451 & 17.05 & 86.08 & 13.92 & 78.70 & 21.30 \\
\hline Election occurrence & -3.956 & 2.633 & 34.95 & 93.20 & 6.799 & 85.06 & 14.94 \\
\hline Political system & 1.400 & 0.574 & 81.10 & 0.815 & 99.19 & 1.705 & 98.30 \\
\hline Years in office of the chief executive & 0.081 & 0.042 & 65.52 & 2.838 & 97.16 & 9.622 & 90.38 \\
\hline Average age of political parties & -0.004 & 0.007 & 0.071 & 72.02 & 27.98 & 68.32 & 31.68 \\
\hline Income inequality & 0.020 & 0.037 & 1.601 & 29.61 & 70.39 & 32.63 & 67.37 \\
\hline Ethnic fragmentation & 0.993 & 1.227 & 0.569 & 21.16 & 78.85 & 23.72 & 76.28 \\
\hline Size of shadow economy & 0.033 & 0.025 & 19.96 & 9.856 & 90.14 & 15.58 & 84.42 \\
\hline Religious fragmentation & -0.724 & 1.282 & 0.000 & 71.03 & 28.97 & 67.93 & 32.07 \\
\hline SSA & 2.355 & 0.955 & 74.94 & 0.756 & 99.24 & 4.354 & 95.64 \\
\hline $\mathrm{ECA}$ & 1.929 & 1.064 & 52.17 & 3.608 & 96.39 & 8.518 & 91.48 \\
\hline MENA & 1.294 & 1.473 & 6.850 & 19.37 & 80.64 & 24.63 & 75.37 \\
\hline EAP & 2.221 & 1.015 & 67.30 & 1.498 & 98.50 & 3.890 & 96.11 \\
\hline LAC & 1.859 & 0.955 & 54.95 & 2.694 & 97.31 & 7.627 & 92.37 \\
\hline Constant & -6.266 & 2.268 & 69.12 & 99.34 & 0.661 & 85.28 & 14.72 \\
\hline
\end{tabular}

Notes : Differences presented are robust to heteroskedasticity. The variance inflation factor (VIF) is set
variables are shown in bold, robust variables in bold and italics, and moderately robust variables in italics. 


\subsection{The problem of multicollinearity}

The problem of multicollinearity is one that is often feared in studies such as ours, involving a large number of explanatory variables. This problem may arise for reasons of conceptual overlap in the definition of explanatory variables or simply for reasons of statistical correlations without any particular economic basis. In both cases, the variables concerned exhibit a strong cross-sectional correlation. In order to test the sensitivity of our results to this problem, we apply additional restrictions by imposing the mutual exclusion rule for pairs of variables displaying a correlation coefficient greater than or equal to 0.5. The cross-correlation matrix between the explanatory variables is presented in Table A-1. We find for example that the level of democracy and the duration in power are negatively correlated with a correlation coefficient of -0.7 , which is not surprising since the least democratic countries are those in which presidents last a long time in power. We therefore impose the non-inclusion of these two variables in the same regression. There is also a strong correlation between the level of economic development and certain institutional variables. All pairs of highly correlated variables are mutually exclusive in the regressions.

EBA results with these additional restrictions are presented in Table 4 . These results broadly corroborate the previous ones. The most robust structural determinants of budget deficits still remain negative external shocks, the debt ratio, the government's inability to control spending, the level of democracy and financial development. The second category of robust variables is composed of the level of economic development, the length of the mandate of the chief executive and, to a lesser extent, the political system and the exchange rate regime. Although the term in office of the chief executive is a new variable in this category, it was already well situated in the previous results. However, as in the previous results, the aggregated CDFs for this variable do not exceed $95 \%$, in particular in the generic model, whereas this is the case for the other variables. 
Table 4: Determinants of the fiscal balance: Multicollinearity sensitivity test

\begin{tabular}{|c|c|c|c|c|c|c|c|}
\hline \multirow[b]{2}{*}{ Variables } & \multirow[b]{2}{*}{ Coef. (Wgt Mean) } & \multirow[b]{2}{*}{ S.E. (Wgt Mean) } & \multirow[b]{2}{*}{ Pct(signif. $\neq 0$ ) } & \multicolumn{2}{|c|}{ Normal model $(\mathrm{N})$} & \multicolumn{2}{|c|}{ Generic model $(\mathrm{G})$} \\
\hline & & & & $\operatorname{CDF}(\beta<=0)$ & $\operatorname{CDF}(\beta>0)$ & $\operatorname{CDF}(\beta<=0)$ & $\operatorname{CDF}(\beta>0)$ \\
\hline External shocks & 0.402 & 0.118 & 95.84 & 0.068 & 99.93 & 0.647 & 99.35 \\
\hline Instability of gov. revenues & -0.006 & 0.010 & 13.79 & 73.29 & 26.71 & 69.32 & 30.68 \\
\hline Economic growth & 0.093 & 0.163 & 0.475 & 28.74 & 71.26 & 32.35 & 67.65 \\
\hline Financial development & -0.038 & 0.012 & 91.84 & 99.87 & 0.130 & 99.10 & 0.896 \\
\hline Inflation rate & 0.008 & 0.017 & 11.50 & 33.47 & 66.53 & 34.77 & 65.23 \\
\hline Log (real GDP per capita) & 0.948 & 0.331 & 79.32 & 0.226 & 99.77 & 4.955 & 95.05 \\
\hline Pegged currency & 0.946 & 0.427 & 67.79 & 1.388 & 98.61 & 3.956 & 96.04 \\
\hline Public debt (\% GDP) & -0.053 & 0.010 & 100.0 & 100.0 & 0.000 & 100.0 & 0.000 \\
\hline Real interest rate & -0.019 & 0.028 & 9.271 & 74.64 & 25.36 & 67.71 & 32.30 \\
\hline Dependency ratio & -5.130 & 2.196 & 60.24 & 98.90 & 1.099 & 92.54 & 7.456 \\
\hline Urbanization rate & 0.033 & 0.016 & 59.57 & 1.766 & 98.23 & 5.260 & 94.74 \\
\hline Political stability & 0.307 & 0.345 & 16.16 & 19.09 & 80.91 & 28.85 & 71.15 \\
\hline Government effectiveness & 0.103 & 0.429 & 7.716 & 40.78 & 59.22 & 49.01 & 50.99 \\
\hline Corruption control & 0.262 & 0.429 & 4.588 & 27.45 & 72.55 & 36.21 & 63.79 \\
\hline Level of democracy & -0.229 & 0.067 & 98.10 & 99.97 & 0.032 & 99.81 & 0.195 \\
\hline Size of Government & -0.394 & 0.307 & 10.14 & 89.72 & 10.28 & 86.90 & 13.10 \\
\hline Gov. control over expenditures & 0.095 & 0.025 & 98.38 & 0.010 & 99.99 & 0.304 & 99.70 \\
\hline Political fragmentation & -1.582 & 1.329 & 12.64 & 88.01 & 11.99 & 81.16 & 18.84 \\
\hline Election occurrence & -4.113 & 2.649 & 38.35 & 93.85 & 6.154 & 85.89 & 14.11 \\
\hline Political system & 1.249 & 0.564 & 69.02 & 1.473 & 98.53 & 2.841 & 97.16 \\
\hline Average age of political parties & -0.006 & 0.007 & 1.783 & 77.74 & 22.26 & 72.77 & 27.23 \\
\hline Income inequality & 0.031 & 0.037 & 6.854 & 20.37 & 79.63 & 25.59 & 74.41 \\
\hline Ethnic fragmentation & 0.761 & 1.193 & 0.634 & 26.40 & 73.60 & 29.09 & 70.91 \\
\hline Size of shadow economy & 0.031 & 0.025 & 17.38 & 10.78 & 89.22 & 15.96 & 84.04 \\
\hline Religious fragmentation & -0.474 & 1.260 & 0.000 & 64.40 & 35.60 & 61.93 & 38.07 \\
\hline SSA & 2.197 & 0.930 & 72.52 & 0.988 & 99.01 & 5.014 & 94.99 \\
\hline ECA & 1.931 & 1.047 & 56.48 & 3.375 & 96.63 & 8.693 & 91.31 \\
\hline MENA & 1.391 & 1.467 & 8.726 & 17.60 & 82.40 & 23.19 & 76.81 \\
\hline EAP & 2.534 & 1.015 & 79.06 & 0.658 & 99.34 & 2.789 & 97.21 \\
\hline LAC & 1.873 & 0.931 & 58.19 & 2.310 & 97.69 & 7.175 & 92.83 \\
\hline Constant & -6.223 & 2.055 & 70.41 & 99.70 & 0.300 & 87.44 & 12.56 \\
\hline
\end{tabular}

Notes : Differences presented are robust to heteroskedasticity. The variance inflation factor (VIF) is set at 5 to avoid the multicollinearity problem. Very robust variables are shown in bold, robust variables in bold and italics, and moderately robust variables in italics. 


\section{Panel regressions and endogeneity issue}

\subsection{Panel regressions}

Cross-section regressions on averaged variables are fairly common and often used to study the structural determinants of budget deficits (see, among others, Morrison, 1982; Roubini, 1991; Woo, 2003a). However, this approach can be criticized for its inability to grasp cyclical phenomena, and especially information not revealed by the variables averaged over a long period. Panel regressions overcome this weakness by introducing a temporal dimension into the analysis. Therefore, we run regressions with a panel dataset that contains non-overlapping 5-year averages of the data for each country. Given the relatively large number of countries, we control for heterogeneity by introducing regional fixed effects and time fixed effects in all the regressions. The results of the regressions are reported in Table 5.

The introduction of the time dimension and shorter averages do not call into question the previous results. Indeed, the robust determinants of the fiscal balance in the cross-sectional analysis - namely external shocks, financial development, level of democracy, public debt ratio and government control over public spending - are identified as such in panel regressions. Similarly, the moderately robust determinants such as the level of economic development and the political regime remain moderately robust in the panel analysis, except the fixed exchange rate regime which becomes robust with a higher level of significance. Furthermore, as might be expected, the introduction of the temporal dimension gives more importance to variables generally associated with economic cycles, such as the instability of public revenues, the economic growth rate and the urbanization rate. These variables and the dependency ratio become moderately robust with a proportion of significance between $70 \%$ and $90 \%$. 
Table 5: Determinants of the fiscal balance: Panel regressions

\begin{tabular}{|c|c|c|c|c|c|c|c|c|}
\hline \multirow[b]{2}{*}{ Variables } & \multirow[b]{2}{*}{ Coef. } & \multirow[b]{2}{*}{ (Wgt Mean) } & \multirow[b]{2}{*}{ S.E. (Wgt Mean) } & \multirow[b]{2}{*}{$\operatorname{Pct}($ signif. $\neq 0)$} & \multicolumn{2}{|c|}{ Normal model $(\mathrm{N})$} & \multicolumn{2}{|c|}{ Generic model $(\mathrm{G})$} \\
\hline & & & & & $\operatorname{CDF}(\beta<=0)$ & $\operatorname{CDF}(\beta>0)$ & $\operatorname{CDF}(\beta<=0)$ & $\operatorname{CDF}(\beta>0)$ \\
\hline External shocks & & 0.272 & 0.090 & 97.029 & 0.130 & 99.870 & 0.399 & 99.601 \\
\hline Instability of gov. revenues & & -0.025 & 0.012 & 71.791 & 97.685 & 2.315 & 88.328 & 11.672 \\
\hline Economic growth & & 0.174 & 0.073 & 75.238 & 0.866 & 99.134 & 2.570 & 97.430 \\
\hline Financial development & & -0.035 & 0.009 & 98.415 & 99.996 & 0.004 & 99.783 & 0.217 \\
\hline Inflation rate & & 0.000 & 0.015 & 18.899 & 51.005 & 48.995 & 62.316 & 37.684 \\
\hline Log (real GDP per capita) & & 1.056 & 0.289 & 85.106 & 0.015 & 99.985 & 1.589 & 98.411 \\
\hline Pegged currency & & 1.085 & 0.346 & 93.582 & 0.088 & 99.912 & 0.741 & 99.259 \\
\hline Public debt (\% GDP) & & -0.042 & 0.007 & 100.000 & 100.000 & 0.000 & 99.999 & 0.001 \\
\hline Real interest rate & & -0.033 & 0.019 & 39.739 & 95.851 & 4.149 & 92.607 & 7.393 \\
\hline Real growth of gov. revenues & & 0.037 & 0.018 & 42.452 & 2.326 & 97.674 & 6.610 & 93.390 \\
\hline Dependency ratio & & -5.118 & 1.636 & 74.269 & 99.903 & 0.097 & 96.199 & 3.801 \\
\hline Urbanization rate & & 0.037 & 0.013 & 88.431 & 0.224 & 99.776 & 1.076 & 98.924 \\
\hline Political stability & & 0.468 & 0.243 & 51.995 & 2.778 & 97.222 & 13.543 & 86.457 \\
\hline Government effectiveness & & 0.116 & 0.336 & 19.213 & 36.673 & 63.327 & 44.195 & 55.805 \\
\hline Corruption control & & 0.333 & 0.327 & 22.540 & 15.576 & 84.424 & 26.971 & 73.029 \\
\hline Level of democracy & & -0.196 & 0.049 & 98.352 & 99.997 & 0.003 & 99.849 & 0.151 \\
\hline Size of Government & & -0.163 & 0.220 & 0.000 & 76.943 & 23.057 & 75.285 & 24.715 \\
\hline Gov. control over expenditures & & 0.048 & 0.011 & 99.326 & 0.000 & 100.000 & 0.037 & 99.963 \\
\hline Political fragmentation & & -1.700 & 1.032 & 38.212 & 94.912 & 5.088 & 87.151 & 12.849 \\
\hline Election occurrence & & -1.932 & 1.371 & 25.317 & 92.016 & 7.984 & 85.426 & 14.574 \\
\hline Political system & & 1.158 & 0.441 & 76.941 & 0.451 & 99.549 & 2.416 & 97.584 \\
\hline Years in office of the chief executive & & 0.070 & 0.036 & 57.992 & 2.776 & 97.224 & 4.566 & 95.434 \\
\hline Average age of political parties & & -0.005 & 0.006 & 3.328 & 79.263 & 20.737 & 74.717 & 25.283 \\
\hline Income inequality & & 0.051 & 0.030 & 35.380 & 4.378 & 95.622 & 6.599 & 93.401 \\
\hline Ethnic fragmentation & & 0.744 & 0.933 & 2.219 & 21.328 & 78.672 & 25.717 & 74.283 \\
\hline Size of shadow economy & & 0.026 & 0.019 & 29.580 & 8.142 & 91.858 & 16.271 & 83.729 \\
\hline Religious fragmentation & & -0.286 & 0.938 & 2.179 & 61.886 & 38.114 & 58.233 & 41.767 \\
\hline SSA & & 2.339 & 0.755 & 89.613 & 0.103 & 99.897 & 1.424 & 98.576 \\
\hline ECA & & 2.720 & 0.758 & 99.353 & 0.018 & 99.982 & 0.162 & 99.838 \\
\hline MENA & & 2.421 & 0.812 & 91.104 & 0.149 & 99.851 & 1.038 & 98.962 \\
\hline EAP & & 1.992 & 1.151 & 40.646 & 4.323 & 95.677 & 10.046 & 89.954 \\
\hline LAC & & 2.995 & 0.870 & 99.400 & 0.030 & 99.970 & 0.202 & 99.798 \\
\hline Constant & & -7.487 & 1.444 & 90.946 & 100.000 & 0.000 & 96.628 & 3.372 \\
\hline
\end{tabular}

Notes : The variance inflation factor (VIF) is set at 5 to avoid the multicollinearity problem. Robust variables are shown in bold, moderately robust variables in bold and italics. All regressions include region fixed effects and time fixed effects. 


\subsection{The issue of endogeneity}

Endogeneity is a recurring question when it comes to analysing the relationships between economic variables, but not only then. This question can arise in the context of our analysis given possible bi-directional causal relationships between the fiscal balance and several of its determinants, such as economic growth, public debt, level of development, the exchange rate regime and the level of democracy. However, it seems difficult if not impossible to adequately address this question in this study given the relatively large number of explanatory variables. It is an almost impossible task to find economically relevant instruments for all of the potential endogenous variables and to technically address this problem with the two-stage least squares (2SLS) method. Furthermore, the use of econometric techniques such as the generalized moments method (GMM) would inexorably induce problems of proliferation of instruments and the explosion of parameters to be estimated.

In summary, although the question of endogeneity is important, the interest of this paper is not to treat this question but rather to highlight the variables linked in a robust way to budgetary deficits, starting from a large number of potential determinants already used in previous studies. Basically, studies whose objective is similar to ours and which rely on a large set of potential determinants do not deal with the issue of endogeneity, even though its importance is not overlooked (see among others, Woo, 2003a; Ghosh and Yamarik, 2004; Serra, 2006; Gassebner, Gutmann, and Voigt, 2016; Bruns and Poghosyan, 2018). However, to control endogeneity to a certain extent, we perform panel regressions with 5-year lagged explanatory variables. The results reported in Table 6 are broadly consistent with the previous ones. All of the robust determinants remain, except for public debt. Furthermore, the level of significance of government control over expenditures is reduced, which shows that rigour in the management of public spending must be permanent. However, the importance of the fixed exchange rate regime becomes greater. 
Table 6: Determinants of fiscal balance: Lagged explanatory variables

\begin{tabular}{|c|c|c|c|c|c|c|c|}
\hline \multirow[b]{2}{*}{ Variables } & \multirow[b]{2}{*}{ Coef. (Wgt Mean) } & \multirow[b]{2}{*}{ S.E. (Wgt Mean) } & \multirow[b]{2}{*}{ Pct(signif. $\neq 0$ ) } & \multicolumn{2}{|c|}{ Normal model $(\mathrm{N})$} & \multicolumn{2}{|c|}{ Generic model $(\mathrm{G})$} \\
\hline & & & & $\operatorname{CDF}(\beta<=0)$ & $\operatorname{CDF}(\beta>0)$ & $\operatorname{CDF}(\beta<=0)$ & $\operatorname{CDF}(\beta>0)$ \\
\hline External shocks & 0.248 & 0.091 & 89.893 & 0.396 & 99.604 & 0.910 & 99.090 \\
\hline Instability of gov. revenues & -0.021 & 0.014 & 21.495 & 92.363 & 7.637 & 86.785 & 13.215 \\
\hline Economic growth & 0.126 & 0.129 & 3.345 & 16.697 & 83.303 & 18.564 & 81.436 \\
\hline Financial development & -0.032 & 0.010 & 89.751 & 99.935 & 0.065 & 98.928 & 1.072 \\
\hline Inflation rate & 0.008 & 0.012 & 7.505 & 28.418 & 71.582 & 37.612 & 62.388 \\
\hline Log (real GDP per capita ) & 1.020 & 0.393 & 67.438 & 0.538 & 99.462 & 6.513 & 93.487 \\
\hline Pegged currency & 1.242 & 0.415 & 93.915 & 0.140 & 99.860 & 0.688 & 99.312 \\
\hline Public debt (\% GDP) & -0.012 & 0.009 & 22.171 & 91.268 & 8.732 & 87.670 & 12.330 \\
\hline Real interest rate & -0.032 & 0.020 & 32.064 & 94.045 & 5.955 & 90.987 & 9.013 \\
\hline Real growth of gov. revenues & 0.010 & 0.014 & 2.313 & 26.915 & 73.085 & 28.770 & 71.230 \\
\hline Dependency ratio & -4.406 & 2.029 & 54.840 & 98.396 & 1.604 & 91.474 & 8.526 \\
\hline Urbanization rate & 0.045 & 0.017 & 84.093 & 0.356 & 99.644 & 1.497 & 98.503 \\
\hline Political stability & -0.063 & 0.300 & 16.113 & 58.226 & 41.774 & 54.767 & 45.233 \\
\hline Government effectiveness & -0.492 & 0.451 & 27.979 & 85.785 & 14.215 & 72.065 & 27.935 \\
\hline Corruption control & -0.185 & 0.399 & 19.092 & 67.664 & 32.336 & 59.273 & 40.727 \\
\hline Level of democracy & -0.190 & 0.059 & 95.996 & 99.924 & 0.076 & 99.473 & 0.527 \\
\hline Size of Government & -0.094 & 0.260 & 0.000 & 64.140 & 35.860 & 63.089 & 36.911 \\
\hline Gov. control over expenditures & 0.027 & 0.012 & 75.125 & 1.540 & 98.460 & 2.612 & 97.388 \\
\hline Political fragmentation & -1.518 & 1.274 & 11.922 & 88.217 & 11.783 & 80.604 & 19.396 \\
\hline Election occurrence & -2.674 & 1.706 & 41.423 & 94.101 & 5.899 & 85.946 & 14.054 \\
\hline Political system & 1.127 & 0.518 & 62.028 & 1.518 & 98.482 & 5.372 & 94.628 \\
\hline Years in office of the chief executive & 0.037 & 0.049 & 2.028 & 22.595 & 77.405 & 26.312 & 73.688 \\
\hline Average age of political parties & -0.004 & 0.007 & 0.142 & 72.720 & 27.280 & 70.214 & 29.786 \\
\hline Income inequality & 0.050 & 0.038 & 2.135 & 9.915 & 90.085 & 11.870 & 88.130 \\
\hline Ethnic fragmentation & 0.389 & 1.127 & 0.463 & 36.524 & 63.476 & 38.671 & 61.329 \\
\hline Size of shadow economy & 0.034 & 0.022 & 32.776 & 6.473 & 93.527 & 13.401 & 86.599 \\
\hline Religious fragmentation & -0.891 & 1.059 & 1.851 & 79.920 & 20.080 & 76.301 & 23.699 \\
\hline SSA & 2.889 & 0.868 & 98.548 & 0.046 & 99.954 & 0.264 & 99.736 \\
\hline ECA & 2.743 & 0.911 & 88.703 & 0.134 & 99.866 & 1.132 & 98.868 \\
\hline MENA & 1.180 & 1.311 & 20.986 & 18.551 & 81.449 & 27.198 & 72.802 \\
\hline EAP & 3.354 & 1.008 & 99.513 & 0.047 & 99.953 & 0.191 & 99.809 \\
\hline LAC & 2.239 & 0.884 & 74.290 & 0.589 & 99.411 & 4.203 & 95.797 \\
\hline Constant & -8.093 & 1.897 & 88.530 & 99.989 & 0.011 & 96.419 & 3.581 \\
\hline
\end{tabular}

Notes : Differences presented are robust to heteroskedasticity. The variance inflation factor (VIF) is set at 5 to avoid the multicollinearity problem. Very robust variables are shown in bold, robust variables in bold and italics, and moderately robust variables in italics. 


\section{Conclusion}

Fiscal policy is a key instrument for the political and economic health of nations. Developing countries and emerging economies often face instability in the management of their public finances, due in particular to their high sensitivity to exogenous shocks but also because of their often controversial economic policy choices. In the 1980s and 1990s, several of these countries experienced excessive budget deficits with debt levels that became unsustainable. This situation led to the implementation of structural adjustment programmes, followed by the "heavily indebted poor countries" initiative for the cancellation of all or part of the external debt of these countries.

The aim of this study is to investigate the structural determinants of budget deficits in emerging and developing countries. The literature points to a relatively large set of potential determinants. This multitude of potential explanatory variables, combined with the absence of a "full" theoretical model of the fiscal balance, raises the question of model uncertainty. To address this concern, we use the Extreme Bound Analysis (EBA) method developed by Sala-i-Martin (1997). This method makes it possible to identify the most robust structural determinants of budget deficits by starting out from a large number of potential determinants and performing thousands of alternative regressions. Our sample consists of 110 emerging and developing countries over two decades (1998-2017).

Our results show that the main structural determinants of fiscal deficits are negative external shocks, the public debt ratio, financial development, the level of democracy and the lack of control over public spending. Public deficits increase significantly with negative external shocks, the public debt ratio, financial development and the level of democracy. Countries in which governments control spending better have fewer budget deficits. In addition, we find that countries with a higher level of development and with a fixed exchange rate regime have fewer budget deficits. The importance of external shocks in all the estimates argues for a diversification of the economies of developing countries in order to mitigate the impact of these shocks, particularly in countries whose public finances are heavily dependent on foreign trade revenues. 


\section{Appendix}

\section{A-1 List of countries}

Aruba, Angola, Albania, United Arab Emirates, Argentina, Azerbaijan, Burundi, Benin, Burkina Faso, Bangladesh, Bulgaria, Bahrain, Bahamas, Bosnia and Herzegovina, Belize, Bolivia, Brazil, Barbados, Brunei, Bhutan, Botswana, Central African Republic, Chile, China, Cote d'Ivoire, Cameroon, Democratic Republic of Congo, Congo, Colombia, Comoros, Cape Verde, Costa Rica, Djibouti, Dominican Republic, Algeria, Ecuador, Egypt, Ethiopia, Fiji, Gabon, Georgia, Ghana, Guinea, Gambia, Guinea-Bissau, Equatorial Guinea, Grenada, Guatemala, Honduras, Croatia, Haiti, Hungary, Indonesia, India, Jamaica, Jordan, Kenya, Kyrgyz Republic, Cambodia, Lebanon, Sri Lanka, Lesotho, Morocco, Moldova, Madagascar, Maldives, Mexico, Macedonia, Mali, Mongolia, Mozambique, Mauritius, Malaysia, Namibia, Niger, Nigeria, Oman, Pakistan, Panama, Philippines, Papua New Guinea, Poland, Paraguay, Qatar, Romania, Russia, Rwanda, Saudi Arabia, Sudan, Senegal, Solomon Islands, Sierra Leone, El Salvador, Suriname, Swaziland, Seychelles, Chad, Togo, Tajikistan, Trinidad and Tobago, Tunisia, Turkey, Tanzania, Uganda, Ukraine, Uruguay, Vietnam, Yemen, South Africa, Zambia.

\section{A-2 Computing the structural fiscal balance}

The cyclically-adjusted fiscal balance is derived from cyclically-adjusted revenues and expenditures. These are calculated as follows:

$$
\begin{aligned}
& R^{A C}=R\left(\frac{Y^{p}}{Y}\right)^{\varepsilon_{R}} . \\
& G^{A C}=G\left(\frac{Y^{p}}{Y}\right)^{\varepsilon_{G}}
\end{aligned}
$$

where $R^{A C}$ et $G^{A C}$ refer to cyclically-adjusted budgetary revenues and expenditures, respectively, $Y^{p}$ potential GDP and $Y$ observed real GDP. $\varepsilon_{R}$ and $\varepsilon_{G}$ measure respectively the elasticity of revenues and the elasticity of expenditures with respect to the output gap (ygap) defined by :

$$
\text { ygap }=\left(\frac{Y-Y^{p}}{Y^{p}}\right)
$$

On this basis, the structural fiscal balance is defined as follows:

$$
S F B=R\left(\frac{Y^{p}}{Y}\right)^{\varepsilon_{R}}-G\left(\frac{Y^{p}}{Y}\right)^{\varepsilon_{G}}
$$


Since the structural fiscal balance measures what the fiscal balance would have been if output were at its potential level, it is fairly common to express it as a percentage of potential output as follows:

$$
s f b=\frac{S F B}{Y^{p}}=\frac{R}{Y^{p}}\left(\frac{Y^{p}}{Y}\right)^{\varepsilon_{R}}-\frac{G}{Y^{p}}\left(\frac{Y^{p}}{Y}\right)^{\varepsilon_{G}}=\frac{R}{Y}\left(\frac{Y^{p}}{Y}\right)^{\varepsilon_{R}-1}-\frac{G}{Y}\left(\frac{Y^{p}}{Y}\right)^{\varepsilon_{G}-1}
$$

Such as $Y^{p} / Y=(y g a p+1)^{-1}$, SFB as a percentage of potential GDP becomes:

$$
s f b=r(1+\text { ygap })^{1-\varepsilon_{R}}-g(1+\text { ygap })^{1-\varepsilon_{G}}
$$

where $s b s$ is the structural budget balance as a percentage of potential GDP and $r$ and $g$ are government revenue and expenditure as a percentage of GDP respectively. To determine potential GDP, we use the Hodrick-Prescott filter $(H P)$ with a conventional value of smoothing parameter $\eta=100$. Potential GDP is the trend component of real GDP extracted from the $H P$ filter.

\section{A-3 Cross-sectional correlations}


Table A-1: Simple correlations among variables

\begin{tabular}{|c|c|c|c|c|c|c|c|c|c|c|c|c|c|c|c|c|c|c|c|c|c|c|c|c|c|c|c|}
\hline Variables & 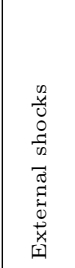 & 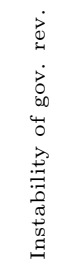 & 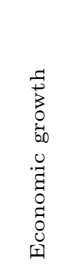 & 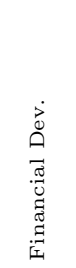 & 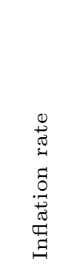 & 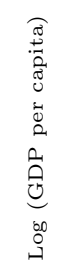 & 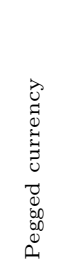 & 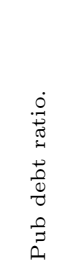 & 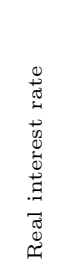 & 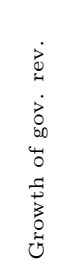 & 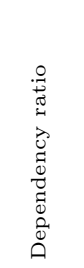 & 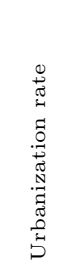 & 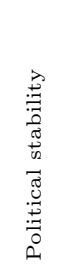 & 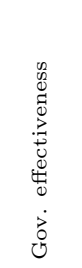 & 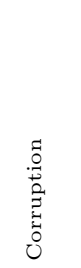 & 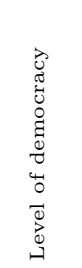 & 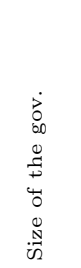 & 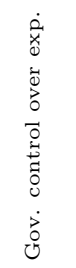 & 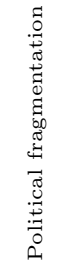 & 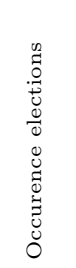 & 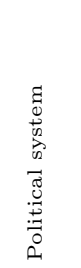 & 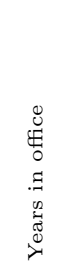 & 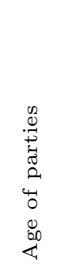 & 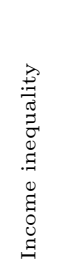 & 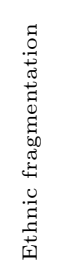 & 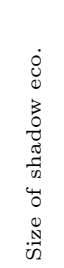 & 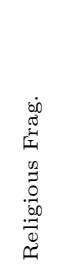 \\
\hline External shocks & 1.00 & & & & & & & & & & & & & & & & & & & & & & & & & & \\
\hline Instability of gov. rev. & -0.14 & 1.00 & & & & & & & & & & & & & & & & & & & & & & & & & \\
\hline Economic growth & 0.16 & -0.14 & 1.00 & & & & & & & & & & & & & & & & & & & & & & & & \\
\hline Financial Dev. & -0.14 & -0.22 & -0.02 & 1.00 & & & & & & & & & & & & & & & & & & & & & & & \\
\hline Inflation rate & 0.08 & -0.09 & 0.06 & -0.28 & 1.00 & & & & & & & & & & & & & & & & & & & & & & \\
\hline Log (real GDP per capita) & 0.17 & -0.29 & -0.17 & 0.52 & -0.23 & 1.00 & & & & & & & & & & & & & & & & & & & & & \\
\hline Pegged currency & 0.19 & 0.18 & 0.04 & 0.16 & -0.34 & 0.08 & 1.00 & & & & & & & & & & & & & & & & & & & & \\
\hline Pub. debt ratio & -0.14 & 0.36 & -0.15 & -0.03 & 0.07 & -0.28 & -0.09 & 1.00 & & & & & & & & & & & & & & & & & & & \\
\hline Real interest rate & -0.19 & 0.08 & -0.14 & -0.10 & 0.10 & -0.12 & -0.21 & 0.14 & 1.00 & & & & & & & & & & & & & & & & & & \\
\hline Real growth of gov. rev. & -0.05 & 0.08 & 0.21 & 0.27 & -0.93 & 0.16 & 0.34 & -0.10 & -0.13 & 1.00 & & & & & & & & & & & & & & & & & \\
\hline Dependency ratio & 0.01 & 0.29 & 0.08 & -0.61 & 0.23 & -0.83 & -0.03 & 0.23 & 0.05 & -0.21 & 1.00 & & & & & & & & & & & & & & & & \\
\hline Urbanization rate & 0.21 & -0.26 & -0.18 & 0.37 & -0.08 & 0.73 & 0.02 & -0.14 & 0.08 & 0.02 & -0.58 & 1.00 & & & & & & & & & & & & & & & \\
\hline Political stability & 0.03 & 0.08 & -0.09 & 0.39 & -0.32 & 0.58 & 0.20 & -0.16 & 0.02 & 0.27 & -0.45 & 0.35 & 1.00 & & & & & & & & & & & & & & \\
\hline Government effectiveness & -0.16 & -0.28 & -0.16 & 0.67 & -0.31 & 0.75 & -0.02 & -0.15 & -0.11 & 0.22 & -0.69 & 0.47 & 0.67 & 1.00 & & & & & & & & & & & & & \\
\hline Control of corruption & -0.16 & -0.07 & -0.19 & 0.53 & -0.29 & 0.63 & 0.08 & -0.09 & -0.05 & 0.19 & -0.55 & 0.39 & 0.76 & 0.89 & 1.00 & & & & & & & & & & & & \\
\hline Level of democracy & -0.33 & -0.06 & -0.35 & 0.09 & 0.01 & 0.01 & -0.34 & 0.06 & 0.19 & -0.06 & -0.07 & 0.05 & 0.18 & 0.21 & 0.17 & 1.00 & & & & & & & & & & & \\
\hline Size of the government & -0.26 & -0.07 & -0.02 & 0.00 & 0.04 & -0.09 & -0.21 & 0.12 & 0.28 & -0.01 & 0.02 & -0.06 & -0.19 & -0.07 & -0.13 & 0.24 & 1.00 & & & & & & & & & & \\
\hline Gov. control over exp. & 0.39 & -0.01 & 0.12 & -0.22 & -0.00 & 0.06 & 0.15 & -0.25 & -0.12 & 0.01 & 0.09 & 0.05 & 0.23 & -0.10 & -0.04 & -0.01 & -0.28 & 1.00 & & & & & & & & & \\
\hline Political fragmentation & -0.14 & -0.11 & -0.28 & -0.17 & 0.14 & -0.15 & -0.26 & 0.03 & 0.20 & -0.17 & 0.03 & -0.06 & -0.27 & -0.16 & -0.22 & 0.56 & 0.14 & -0.05 & 1.00 & & & & & & & & \\
\hline Occurence elections & 0.06 & 0.11 & -0.15 & -0.21 & -0.09 & -0.08 & -0.15 & 0.05 & 0.10 & 0.06 & 0.00 & 0.10 & -0.01 & -0.15 & -0.20 & 0.37 & -0.01 & 0.10 & 0.43 & 1.00 & & & & & & & \\
\hline Political system & 0.18 & 0.04 & 0.11 & -0.39 & 0.09 & -0.17 & -0.03 & -0.07 & 0.20 & -0.07 & 0.31 & 0.12 & -0.18 & -0.27 & -0.22 & -0.25 & -0.02 & 0.04 & -0.01 & 0.08 & 1.00 & & & & & & \\
\hline Years in office & 0.34 & -0.05 & 0.17 & -0.15 & 0.09 & 0.10 & 0.22 & -0.16 & -0.15 & -0.10 & 0.14 & 0.01 & 0.03 & -0.07 & -0.09 & -0.70 & -0.24 & 0.27 & -0.52 & -0.30 & 0.29 & 1.00 & & & & & \\
\hline Age of political parties & -0.08 & -0.18 & -0.04 & 0.31 & 0.00 & 0.20 & -0.05 & 0.10 & 0.05 & -0.01 & -0.18 & 0.23 & 0.06 & 0.25 & 0.19 & 0.11 & 0.09 & -0.09 & -0.16 & -0.26 & -0.13 & -0.09 & 1.00 & & & & \\
\hline Income inequality & 0.08 & 0.11 & -0.17 & 0.00 & 0.03 & -0.00 & 0.08 & -0.11 & 0.20 & -0.10 & 0.23 & 0.08 & 0.13 & 0.02 & 0.14 & 0.18 & 0.10 & 0.07 & 0.02 & -0.10 & 0.16 & -0.12 & 0.24 & 1.00 & & & \\
\hline Ethnic fragmentation & 0.12 & 0.07 & 0.11 & -0.32 & 0.18 & -0.37 & 0.02 & 0.08 & 0.05 & -0.16 & 0.43 & -0.11 & -0.24 & -0.27 & -0.25 & -0.14 & -0.04 & 0.06 & -0.01 & -0.02 & 0.26 & 0.19 & -0.21 & 0.04 & 1.00 & & \\
\hline Size of shadow economy & -0.00 & 0.19 & -0.11 & -0.48 & 0.17 & -0.45 & -0.06 & 0.10 & 0.26 & -0.19 & 0.47 & -0.25 & -0.32 & -0.50 & -0.44 & 0.07 & 0.14 & 0.08 & 0.27 & 0.26 & 0.31 & -0.07 & -0.19 & 0.18 & 0.27 & 1.00 & \\
\hline Religious Frag. & 0.03 & -0.02 & -0.14 & 0.03 & 0.11 & -0.16 & 0.02 & 0.11 & 0.01 & -0.13 & 0.13 & -0.22 & -0.01 & -0.02 & -0.02 & 0.07 & -0.10 & 0.09 & 0.05 & -0.05 & -0.32 & -0.07 & -0.09 & 0.15 & 0.33 & 0.20 & 1.00 \\
\hline
\end{tabular}




\section{References}

Alesina, A., A. Devleeschauwer, W. Easterly, S. Kurlat, and R. WACZiArg (2003): "Fractionalization," Journal of Economic Growth, 8(2), 155-194.

Alesina, A., And A. Drazen (1991): "Why are Stabilizations Delayed?," The American Economic Review, 81(5), 1170-1188.

Alesina, A., And D. Rodrik (1994): "Distributive Politics and Economic Growth," The Quarterly Journal of Economics, 109(2), 465-490.

Benfratello, L., A. D. Monte, and L. Pennacchio (2018): "Corruption and public debt: a cross-country analysis," Applied Economics Letters, 25(5), 340-344.

Brender, A., And A. Drazen (2005): "Political budget cycles in new versus established democracies," Journal of Monetary Economics, 52(7), 1271 - 1295, Political economy and macroeconomics.

Bruns, M., And T. Poghosyan (2018): "Leading indicators of fiscal distress: evidence from extreme bounds analysis," Applied Economics, 50(13), 1454-1478.

Clarke, G. R. (1995): "More evidence on income distribution and growth," Journal of Development Economics, 47(2), 403 - 427.

Collier, P. (2000): "How to Reduce Corruption," African Development Review, $12(2), 191-205$.

Combes, J.-L., And T. SAAdi-SediK (2006): "How does trade openness influence budget deficits in developing countries?," Journal of Development Studies, 42(8), 1401-1416.

DE HaAn, J. (2014): "Democracy, Elections and Government Budget Deficits," German Economic Review, 15(1), 131-142.

de HaAn, J., And J.-E. Sturm (1997): "Political and economic determinants of OECD budget deficits and government expenditures: A reinvestigation," European Journal of Political Economy, 13(4), 739 - 750.

Ebeke, C. H., and H. Ehrhart (2012): "Does VAT reduce the instability of tax revenues?," working paper or preprint.

Ebeke, C. H., And D. ÖlCER (2013): "Fiscal Policy over the Election Cycle in Low-Income Countries," IMF Working Papers 13/153, International Monetary Fund. 
EDWARDS, S., AND G. TABEllini (1991): "Explaining fiscal policies and inflation in developing countries," Journal of International Money and Finance, 10, S16 S48.

Elgin, C., And B. R. URAs (2013): "Public debt, sovereign default risk and shadow economy," Journal of Financial Stability, 9(4), 628 - 640, Re-examining the role of the state in the financial sector.

Fedelino, A., M. A. Horton, and A. Ivanova (2009): "Computing CyclicallyAdjusted Balances and Automatic Stabilizers," IMF Technical Notes and Manuals 09/05, International Monetary Fund.

Gassebner, M., J. Gutmann, and S. Voigt (2016): "When to expect a coup d'état? An extreme bounds analysis of coup determinants," Public Choice, 169(34), 293-313.

Ghosh, S., And S. YAmARIK (2004): "Are regional trading arrangements trade creating?: An application of extreme bounds analysis," Journal of International Economics, 63(2), 369 - 395.

Hlavac, M. (2016): "ExtremeBounds: Extreme Bounds Analysis in R," Journal of Statistical Software, Articles, 72(9), 1-22.

Kim, D.-H., Y.-C. WU, AND S.-C. LiN (2018): "Heterogeneity in the effects of government size and governance on economic growth," Economic Modelling, $68(\mathrm{C}), 205-216$.

Leamer, E. E. (1985): "Sensitivity Analyses Would Help," The American Economic Review, 75(3), 308-313.

Liu, C., T. T. Moldogaziev, and J. L. Mikesell (2017): "Corruption and State and Local Government Debt Expansion," Public Administration Review, $77(5), 681-690$.

Medina, L., And F. Schneider (2018): "Shadow Economies Around the World: What Did We Learn Over the Last 20 Years?," IMF Working Papers 18/17, International Monetary Fund.

Morrison, T. K. (1982): "Structural determinants of government budget deficits in developing countries," World Development, 10(6), $467-473$.

Persson, T., and G. Tabellini (1994): "Is Inequality Harmful for Growth?," The American Economic Review, 84(3), 600-621. 
(1999): "The size and scope of government: Comparative politics with rational politicians," European Economic Review, 43(4), 699 - 735.

RAM, R. (1989): "Government Size and Economic Growth: A New Framework and Some Evidence from Cross-Section and Time-Series Data: Reply," The American Economic Review, 79(1), 281-284.

Roubini, N. (1991): "Economic and political determinants of budget deficits in developing countries," Journal of International Money and Finance, 10, S49 S72.

Roubini, N., And J. D. SACHS (1989): "Political and economic determinants of budget deficits in the industrial democracies," European Economic Review, 33(5), $903-933$.

Sala-I-Martin, X. (1997): "I Just Ran Two Million Regressions," American Economic Review, 87(2), 178-183.

Scartascini, C., C. Cruz, and P. Keefer (2018): "The Database of Political Institutions 2017 (DPI2017)," .

Schuknecht, L. (2000): "Fiscal Policy Cycles and Public Expenditure in Developing Countries," Public Choice, 102(1/2), 115-130.

SERrA, D. (2006): "Empirical Determinants of Corruption: A Sensitivity Analysis," Public Choice, 126(1/2), 225-256.

Shugart, M. S., And J. M. Carey (1992): Presidents and Assemblies: Constitutional Design and Electoral Dynamics. Cambridge University Press.

Steiner, A. (2017): "Determinants of the Public Budget Balance: The Role of Official Capital Flows," No. D19-V1 in Beiträge zur Jahrestagung des Vereins für Socialpolitik 2017: Alternative Geld- und Finanzarchitekturen - Session: Taxation IV, Kiel, Hamburg. ZBW - Deutsche Zentralbibliothek für Wirtschaftswissenschaften, Leibniz-Informationszentrum Wirtschaft.

Tornell, A., And A. Velasco (1995): "Fiscal discipline and the choice of exchange rate regime," European Economic Review, 39(3), 759 - 770, Papers and Proceedings of the Ninth Annual Congress European Economic Association.

(2000): "Fixed versus flexible exchange rates: Which provides more fiscal discipline?," Journal of Monetary Economics, 45(2), 399 - 436. 
Tujula, M., And G. Wolswijk (2004): "What determines fiscal balances? An empirical investigation in determinants of changes in OECD budget balances," Working Paper Series 422, European Central Bank.

Volkerink, B., And J. D. HaAn (2001): "Fragmented Government Effects on Fiscal Policy: New Evidence," Public Choice, 109(3/4), 221-242.

Woo, J. (2003a): "Economic, political, and institutional determinants of public deficits," Journal of Public Economics, 87(3), 387 - 426.

(2003b): "Social polarization, industrialization, and fiscal instability: theory and evidence," Journal of Development Economics, 72(1), 223 - 252.

(2009): "Why Do More Polarized Countries Run More Procyclical Fiscal Policy?," The Review of Economics and Statistics, 91(4), 850-870. 